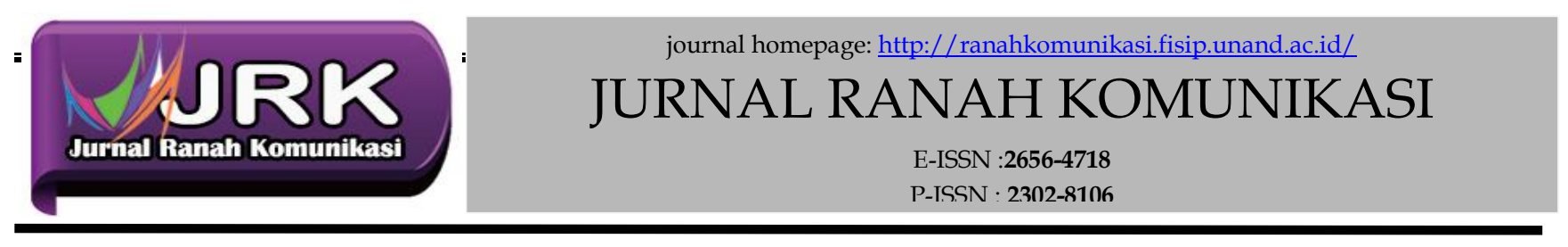

\title{
SISTEM KERJA VIRTUAL PHOTOSHOOT DITENGAH PANDEMI COVID-19
}

\author{
Rangga Alfara1), Dasrun Hidayat ${ }^{2)}$ \\ 1) Fakultas Ilmu Komunikasi, Universias Adhirajasa Reswara Sanjaya, E-mail: Ranggaalfara1@gmail.com \\ 2) Universias Adhirajasa Reswara Sanjaya, Jl. Sekolah Internationnal No.1-2, Bandung, E-mail: dasrun@ars.ac.id
}

ARTICLE INFORMATION

KEYWORDS:

Virtual Photoshoot, Photography, Covid-19

CORRESPONDENCE

Phone: 082119165034

E-mail: Ranggaalfara1@gmail.com

\section{A B S T R A C T}

\section{Abstract}

Virtual photoshoot is a photography trend nowadays. Where virtual photoshoots are an alternative business activity for photographers in the midst of a social distancing policy due to the Covid-19 pandemic outbreak. The method in this study used a qualitative descriptive method, and then a phenomenological study approach was carried out. The research sampling was carried out through purposive sampling method, namely the virtual photoshoot actors in the city of Bandung. The results in this study indicate the creative aspects of the virtual photoshoot which consist of methods, creative processes and obstacles. Meanwhile, the aspect of consumer trust consists of establishing a portfolio, educating the virtual photoshoot stage and targeting new potential markets. Whereas the virtual media photoshoots used consisted of social media references, media technology and the relationship between technology and photography media in order to improve business activities amid the ongoing Covid-19 pandemic.. Keywords: Virtual Photoshoot, Photography, Covid-19

\section{INTRODUCTION}

Industri kreatif merupakan industri yang berlandaskan pada kreatifitas, kompetensi dan bakat individu dalam menciptakan lapangan pekerjaan melalui pemanfataan daya kreasi dan daya cipta individu pelakunya, dimana industri kreatif dapat dibagi menjadi 14 bidang, diantaranya adalah arsitektur, desain, fashion, film, video dan fotografi, kerajinan, layanan komputer dan piranti lunak, musik, pasar dan barang seni, penerbit dan percetakan, periklanan, permainan interaktif, riset dan pengembangan, pertunjukan, serta televisi dan radio (Sirat et al., 2019)

Keberadaan industri berbasis kreatif di Indonesia saat ini dapat dimanfaatkan sebagai media yang efektif dalam membangun image dan identitas negara, hal tersebut dikarenakan melalui industri kreatif nilai-nilai yang bersifat kebangsaan dapat diekspor sebagai komoditi industri yang potensial kepada khalayak internasional. Selain daripada itu industri kreatif dapat membentuk iklim bisnis yang positif, dimana daya kreasi, inovasi dan pengembangan sumber daya manusia menjadi nilai keunggulan 
kompetitif bagi pihak-pihak yang terlibat didalamnya (Rahmasari, 2011)

Karenanya dalam rangka mewujudkan industri kreatif sebagai sarana dalam meningkatkan perekonomian negara, maka dibutuhkan upaya pemetaan potensi industri pada tiap-tiap sektornya, dimana peranan pemerintah sangat penting dalam mendorong pertumbuhan industri kreatif lebih baik lagi (Agustina et al., 2014). Dari berbagai sektor industri kreatif yang ada di Indonesia, salah satu sub sektor yang mengalami perkembangan cukup baik dan saat ini banyak diminati oleh masyarakat adalah bidang Fotografi. Keberadaan media sosial mendorong kebutuhan masyarakat terhadap bukti visual sebagai eksistensi diri secara sosial. Lebih jauh dengan meingkatnya penggunaan media sosial membawa arah baru terhadap fotografi.

Kebutuhan masyarakat terhadap eksistensi diri secara visual dan narsisme menjadi pemicu pertumbuhan kebutuhan media visual setiap waktunya (Purnomo, 2018). Tidak kurang dari 1,8 milyar foto diunggah ke media sosial setiap harinya yang menyebabkan perubahan dinamika fotografi sebagai media yang mengalami perkembangan yang sangat pesat (Purnomo, 2018). Perkembangan bisnis fotografi di Indonesia dimulai sejak awal tahun 2000-an, dimana fotografi menjadi bidang komunikasi visual yang banyak digemari oleh masyarakat Indonesia, khsusnya pada segmen usia muda.

Dengan semakin berkembangnya teknologi di bidang fotografi berdampak pada peningkatan minat untuk menggunakan jasa fotografer yang semakin banyak, sehingga berdampak pada intensitas persaingan usaha semakin kompetifif (Widiatmojo, 2018). Selain daripada itu peluang bisnis di industri fotografi tidak akan pernah berhenti selama masih banyak masyarakat yang memerlukan suatu hasil karya untuk mengabdikan momen berharga dalam hidupnya, sehingga bisnis fotografi menjadi bisnis usaha yang sangat menjanjikan (Nugroho,
2014). Tiap industri akan mengalami pasang surut yang disebabkan oleh berbagai faktor, salah satunya disebabkan oleh terjadinya wabah Covid-19 seperti yang terjadi saat ini.

Virus corona adalah sekumpulan virus yang berasal dari subfamily Orthocronavirinae didalam family Coronaviridae maupun ordo Nidovirales. Virus corona dapat menjangkiti pada spesies burung dan mamalia, dimana salah satunya adalah manusia, sehingga dampak virus corona terhadap kesehatan manusia menyebabkan infeksi pada saluran pernafasan menyebabkan gejala seperti influenza sampai dengan kematian (Yunus \& Rezki, 2020). Banyaknya jumlah kematian yang disebabkan oleh virus Corona secara global menyebabkan pemerintah memberlakukan kebijakan dalam menekan penularan virus corona kepada masyarakat.

Bentuk kebijakan untuk memutus matarantai COVID-19 diantaranya adalah dengan membatasi aktifitas keluar rumah (Pratama \& Hidayat, 2020). Termasuk kegiatan pembelajran pun juga dilakukan dari rumah (Hidayat \& Noeraida, 2020). Ketentuan tersebut intinya melarang kegiatan yang bersifat keramaian, dan melakukan kegiatan pekerjaan dari rumah (work from home) (Yunus \& Rezki, 2020). Usaha di bidang fotografi adalah usaha yang banyak bergerak di lapangan, dimana keterlibatan banyak orang atau massa menjadi salah satu kondisi kerja yang tidak dihindari, dimana dampak dari diberlakukanya kebijakan social distancing menyebabkan kegiatan sosial yang memerlukan jasa dokumentasi jauh berkurang, dimana banyak sekali fotografer wedding harus membatalkan pemotretan di luar kota atau luar negeri karena sebagian besar lokasi populer seperti Bali, Jepang, Singapura dan Jepang ditutup (Tjin, 2020)

Lebih jauh industri fotografi pada aspek produsen gir, lensa, kamera akan terganggu disebabkan oleh tertundanya supply chain permintaan pada kamera, lensa dan komponenya (Tjin, 2020) Untuk mengetahui dampak pada 
pelaku usaha di industri berbasis kreatif di Indonesia, maka survei daring dilakukan oleh Serikat para Pekerja Media maupun Industri Kreatif untuk Demokrasi (Sindikasi) sejak 20 Maret sampai dengan 4 April 2020 dengan 139 responden pekerja lepas dari beberapa subsektor industri media dan kreatif di kota besar di Indonesia, dimana hasil survey menyebutkan bahwa dikarenakan terjadinya pembatalan projek meyebabkan banyak freelancer tidak memiliki pendapatan sama sekali (Marvela, 2020).

Data perkiraan pendapatan yang hilang akibat pembatalan pekerjaan pada krisis Covid19 terbesar di kisaran Rp5-15 juta (32,8 persen) dan > Rp1-5 juta (32,8 persen). Selain itu, ada yang harus kehilangan pendapatan > Rp15-30 juta sebanyak 16,8 persen hingga di atas Rp60 juta (3,6 persen) (Marvela, 2020). Subsektor yang paling banyak terjadi pembatalan pekerjaan secara berturut-turut dikarenakan wabah virus Corona diantaranya film, video, audio sebanyak $17,35 \%$, seni pertunjukan sebanyak $10,8 \%$, seni vokal dan musik sebanyak 9,4\%, fotografi sebanyak $9,4 \%$, penelitian sebanyak $7,2 \%$, dan desain komunikasi visual sebanyak 7,2\% (Nugraha, 2020) Agar mampu tetap bertahan ditengah terjadinya pandemic virus Corona, maka pelaku usaha fotografi harus mampu menyiasati kegiatan usahanya melalui pemanfaatan teknolgi informasi berbasis internet (Aryanto, 2020). Virtual Photoshoot atau bisa juga disebut juga dengan sesi pemotretan dari jarak jauh sedang menjadi tren saat ini.

Dengan merebaknya wabah virus Corona maka teknik virtual photoshoot menjadi salah satu cara agar pelaku usaha fotografi dapat bertahan (Dewi, 2020). Virtual Photoshoot merupakan Teknik pemotretan yang sederhana, dimana fotografer melakukan video call melalui perangkat komputer dengan klien, klien diarahkan untuk melakukan berbagai poshe untuk kemudian dilakukan pemtretan dengan kamera tertentu, dimana selanjutnya hasil pemotretan diedit dan dikirimkan beberapa waktu kemudian (Dewi, 2020) .
Dalam perkembangan industri fotografi modern, teknologi fotografi ditunjang dengan teknolgi digital filing, dimana rol film sudah tidak digunakan lagi untuk menyimpan hasil pemotretan (Peranika \& Martana, 2018). Sehingga hal tersebut mempermudah pemanfaatan teknolgi internet sebagai media interaksi bisnis dengan konsumen. Memaksimalkan layanan secara online menjadi strategi yang efektif dalam menjalankan kegiatan bisnisnya, dimana banyak metode yang dapat digunakan dalam memaksimalkan bisnis fotografi secara online (Perwitasari, 2020)

Dengan tingginya pengguna sosial media di Indonesia, maka virtual photoshoot dapat menjadi peluang usaha yang menjanjikan, dimana skema usaha dapat diatur sedemikian rupa sehingga tingkat kepercayaan dapat terjalin dengan baik dengan konsumen. Perkembangan teknologi informasi yang terjadi saat ini seharusnya dapat menjadi peluang bagi setiap pelaku usaha fotografi untuk mengembangan ragam usaha dan layananya kepada konsumen secara online melalui internet.

Literature Review

\section{Komunikasi Massa}

Komunikasi Massa Komunikasi massa merupakan komunikasi yang dilakukan melalui media, seperti surat kabar, film, radio, internet dan televisi, dalam penelitian penelitian keberadaan komunikasi massa erat dengan subjek penelitian peneliti, yaitu perihal teknik virtual photoshoot di industri fotografi ditengah pandemi covid-19. Komunikasi Massa menurut (Rakhmat, 2013), komunikasi massa dapat diefinisikan sebagai bentuk komunikasi bagi khalayak luas, baik secara heterogen maupun anonym yang disebarkan melalui media elektronik ataupun cetak sehingga pesan yang disampaikan dapat diterima secara serentak.

Komunikasi massa merupakan adopsi yang berasal dari mass communication yang menggunakan media massa sebagai alat penyampainya. Poll pada tahun (1973) memberikan pengertian komunikasi massa adalah suatu betuk komunikasi yang terjadi 
secara interposed, yaitu Ketika sumber maupun penerima teidak terdapat kontak secara langsung, sehingga pesan yang disampaikan mengalir melalui saluran media seperti majalah, surat kabar, radio, film dan lain sebagainya (Wiryanto, 2003).

\section{Konvergensi Media}

Adapun Media Konvergensi adalah istolah yang berasal dari istiah dalam Bahasa inggris yaitu convergence, konvergensi mengarah pada dua benda atau sesuatu yang bertemu pada satu titik (Arismunandar, 2006). Konvergensi media menyebabkan perubahan radikal dalam penanganan, penyedian dan distribusi dan pemrosesan seluruh bentuk informasi baik visual,audio, data dan sebagai nya (Preston, 2011) perkembangan internet dan konvergensi media Internet pada dasar nya merupakan suatu sistem dalam jaringan komputer, dimana bentuknya merupakan personal computer ( $\mathrm{pc}$ ) yang ada di seluruh belahan dunia baik di rumah rumah maupun kator sebagai terminal media komunikasi yang serba guna untuk dapat digunakan menerima maupun mengitim sinyal seperti suara, gambar dan data, internet sebagai salah satu kunci yang memankan peran penting dalam pembentukan media baru juga di tegaskan oleh pernyataan Don Tapscoot, direktur alliance of converging technologies, sebagai berikut: The traditional media of the fourth estate (originally called the press) are converging with computing and telecommunication to create nothing es than a new medium of human communication with the net at its heart ( Patricia et al, 1998 ).

\section{New Media}

Istilah New Media dapat diartikan sebagai media baru yang memiliki kedekatan dengan keseharian setiap orang. Lebih jauh untuk memahami media baru secara lebih jauh maka harus mengenal terlebih dahulu istilah media. Perkembangan teknologi yang sangat pesat ini banyak mempengaruhi kehidupan masyarakat khususnya di Indonesia.

Media konvensional seperti koran, radion dan televisi merupakan media yang banyak digunakan sebagai media untuk menyampaikan pesan kepada khalayak luas. Namun saat ini dengan adanya keberadaan smartphone menyebabkan banyaknya informasi yang bisa diperoleh khalayak luas melalui pengaksesan portal media massa berbasis online ataupun melalui media sosial. media sosial merupakan media yang penyampaiannya dilakukan secara online yang memudahkan pengguna untuk berperan aktif dalam bertukaran dengan ciri informasinya dari satu kebanyak sasaran (Budiman et al., 2019). Menurut Karjaluoto menyatakan terdapat 6 macam media sosial yaitu: 1.Blog 2.Forum 3.Komunikasi konten 4.Dunia Virtual 5.Wikis 6.Jejaring sosial (Budiman et al., 2019).

Internet merupakan media yang popular dan banyak digunakan oleh masyarakat saat ini. Dimana keberadaan internet menjadi suatu hal yang tidak dapat dilepaskan oleh gaya hidup masyarakat kini. Kemudahan akses menyebabkan semakin tumbuhnya media berita online yang menyebabkan semakin ditinggalkanya media konvensional saat ini. Dimana keberadaan internet juga berdanpak pada beralihnya portal berta konvebsional ke media berita online. Dengan adanya sambungan internet khalayak dapat memilih media sosial yang mereka inginkan dan dapat di gunakan kapan dan dimanapun mereka inginkan (Hanana et al., 2020).

Portal berita yang cukup popular di Indonesia adalah kompas.com, dimana kompas diawali oleh media cetak untuk kemudian berkembang menjadi kompas tv dan portal berita online yaitu kompas.com. pengapliaksian konsep new media telah dilakukan oleh kompas.

Kompas telah berfokus pada pengembangan media tv sebagai media paling besar yang disusul dengan keberadaan media berita online sebagai fokus pengembangan media berbasis internet. 
Keberadaan internet menjadikan kompas mudah diakses dan memberikan kenyamanan kepada pembaca untuk melakukan akses pada bentuk informasi yang dicari

\section{Interactivity}

Penerapan interactivity dalam kompas menyebabkan khalayak tidak saja sebagai pihak yang pasif, tetapi diberikan dorongan untuk bersikap aktif melalui media komentar yang disediakan dibawah informasi berita untuk menyampaikan aspirasi dan pendapartnya mengenai informasi yang tersaji di halman website

\section{Hypertextual}

Hypertextual merupakan bentuk aktifasi khalayak dengan menyebarluaskan atau share link dimedia sosialnya masing-masing dengan tujuan supaya infromasi dapat tersebar dengan luas dan cepat.

\section{Networked}

Karakteristik netwrorked menjadi hal yang dimiliki oleh portal media apapun. Dimana kemudahan akses informasi dari berbagai belahan dunia menjadi keunggulan portal media berbasis internet

\section{Virtual}

Kelebihan media berbasis online terdapat pada fitur pemutana audio visual yang dapat meningkatkan pemahaman dan ketertarikan khalayak untuk membaca informasi yang dismapaikan

\section{Simulated}

Simulated dapat menjadikan khalayak berintaeraksi seperti didunia nyata melalui pemanfaatan media komentar

\section{Teori Determinisme}

Teori yang relevan pada penelitian ini adalah Teknologi Determinisme. Teori ini dikemukakan oleh Marshall McLuhan pertama kali pada tahun 1962 dalam tulisannya The Guttenberg Galaxy: The Making of Typographic man. Ia juga sempat menulis buku yaitu Understanding Media (1964), ia menulis tentang pengaruh teknologi. Ide dasar teori ini adalah perubahan yang terjadi dalam berkomunikasi akan membentuk keberadaan manusia itu sendiri. teknologi akan berpengaruh terhadap pola hidup dalam berfikir, berperilaku dalam masyarakat dan menjadi manusia yang lebih kekinian mengikuti zaman. McLuhan (2009) berpendapat bahwa teknologi dapat merubah budaya yang dibentuk oleh bagaimana caranya manusia berkomunikasi. Ada beberapa tahap manusia dalam mengenal media komunikasi. Pertama, teknologi dapat merubah kebudayaan. Kedua, jenis-jenis komunikasi dapat membentuk manusia. Ketiga, seperti yang disampaikan McLuhan "Kita membentuk peralatan untuk berkomunikasi dan akhirnya peralatan untuk berkomunikasi yang kita gunakan akan membentuk atau memengaruhi kehidupan kita sendiri."

Tahapan manusia mengenal media komunikasi dalam perspektif McLuhan pada premis ketiga, sangat menekankan akan keberadaan penelitian peneliti, yang dimana manusia disini adalah para fotografer yang membentuk peralatan komunikasi yang disini berarti adalah media informasi berbasis video conference sebagai alat komunikasi, yang pada akhirnya akan dijadikan untuk membentuk teknik pada proses pemotretan. Teknologi begitu memberikan peranan penting bagi setiap kehidupan manusia. Hampir setiap orang bergantung pada teknologi karena setiap detik mereka menggunakannya. McLuhan menganggap teknologi menjadi sebuah revolusi baru ditengah masyarakat dan media berperan menciptakan dan mengolah budaya

\section{METHOD}

Metode yang digunakan dalam penelitian ini adalah metode deskriptif kualitatif dengan pendekatan studi fenomenologi. "fenomenologi adalah menguhubungkan antara pengetahuan ilmiah dengan pengalaman sehari-hari, dan dari kegiatan dimana pengalaman dan pengetahuian itu berasal. Dengan kata lain fenomenologi mendasarkan tindakan sosial pada pengalaman, makna dan kesadaran." (Kuswarno, 2013) Fenomenologi digunakan peneliti karena peneliti 
berupaya menggambarkan fenomena dari para profesional fotografer yang tetap bertahan ditengah pandemi covid-19 dengan menggunakan metode teknik virtual photoshoot.

Peneliti menggunakan paradigma konstruktivis karena peneliti ingin memaparkan tentang konstruksi makna reputasi profesional fotografer tetap bertahan ditengah pandemi covid-19 dengan menggunakan metode teknik virtual photoshoot itu sendiri sebagai hasil dari suatu realita sosial yang bersifat relatif. Creswell meneguhkan bahwa; "Konstrukstivisme sosial meneguhkan asumsi bahwa individ-individu selalu berusaha memahami dunia dimana mereka hidup dan bekerja. Mereka meningkatkan makna subjektif atas pengalaman mereka, makna yang ditujukan pada benda atau objek tertentu (Creswell, 2010).

Subjek penelitian yang diteliti untuk menjadi pembahasan dalam penelitian adalah para fotografer yang melakukan metode fotografi Virtual Photoshoot sebagai solusi menurunya pendapatan kerja ditengah terjadinya wabah pandemi Covid-19.

Objek penelitian pada penelitian ini adalah mengenai teknik baru para profesional fotografer ditengah pandemi covid-19 melalui penggunaan berbagai teknik dan apliaksi baru sebagai sarana untuk mendapatkan hasil yang maksimal. Adapun jenis data dalam penelitian ini adalah data primer dan sekunder. Data primer terdiri dari hasil observasi dan wawancara, sedangkan data sekunder diperoleh melalui kajian terhadap berbagai literatur yang terkait dengan penelitian ini.

Data yang sudah terkumpul pada proses pengumpulan data, tahap selanjutnya adalah peneliti menganalisa data. Pada tahap ini peneliti melalukan proses pengumpulan semua data dan kemudian menyusun data secara sistematis. Data tersebut adalah data yang peneliti peroleh dari hasil wawancara mendalam dengan para profesional fotogrfaer dan dokumentasi. Keseluruhan data yang telah terkumpul tersebut selanjutnya dibuat pengelompokan atau mengkategorisasikan. Kategori yang dibuat peneliti yaitu kategori berdasarkan pemaknaan pada profesional fotografer tetap bertahan ditengah pandemi covid-19 dengan menggunakan metode teknik virtual photoshoot.

Teknik pemeriksaan keabsahan data yang peneliti gunakan yaitu Triangulasi data. Menurut (Moleong, 2010), triangulasi adalah teknik pemeriksaan keabsahan sebagai pengecekan data dari berbagai sumber dengan berbagai cara dan berbagai waktu.

\section{RESULTS AND DISCUSSION}

Virtual Photoshoot atau bisa juga disebut juga dengan sesi pemotretan dari jarak jauh sedang menjadi tren beberapa bulan yang lalu dengan kehadirannya ketika Dunia dihadapkan dengan wabah besar yaitu pandemi Covid-19, seluruh sektor terdampak dengan adanya pandemi ini, bahkan pada fokus penelitian ini, sektor industri kreatif seperti fotografi juga menjadi bagian terdampaknya pandemi tersebut.

Dimensi hasil temuan penelitian yang akan peneliti jelaskan pada bab pembahasan ini, yaitu mengenai proses kreatif Virtual Shoot, pembentukan kepercayaan pihak eksternal, dan media yang digunakan virtual photoshoot

\section{Proses Kreatif Virtual Photoshoot}

Proses kreatif yang dilakukan pada saat Virtual Photoshoot akan peneliti uraikan dalam pembahasan analisa hasil penelitian, yang dalam penelitian nya menemukan tiga hasil temuan penelitian, yaitu proses teknis Virtual Photoshoot, proses penemuan kreatifitas Virtual Photoshoot, dan kendala secara teknis yang ditemui pada saat melakukan Virtual Photoshoot. Ketiga aspek tersebut secara lebih jelas dapat dilihat pada gambar sebagai berikut: 


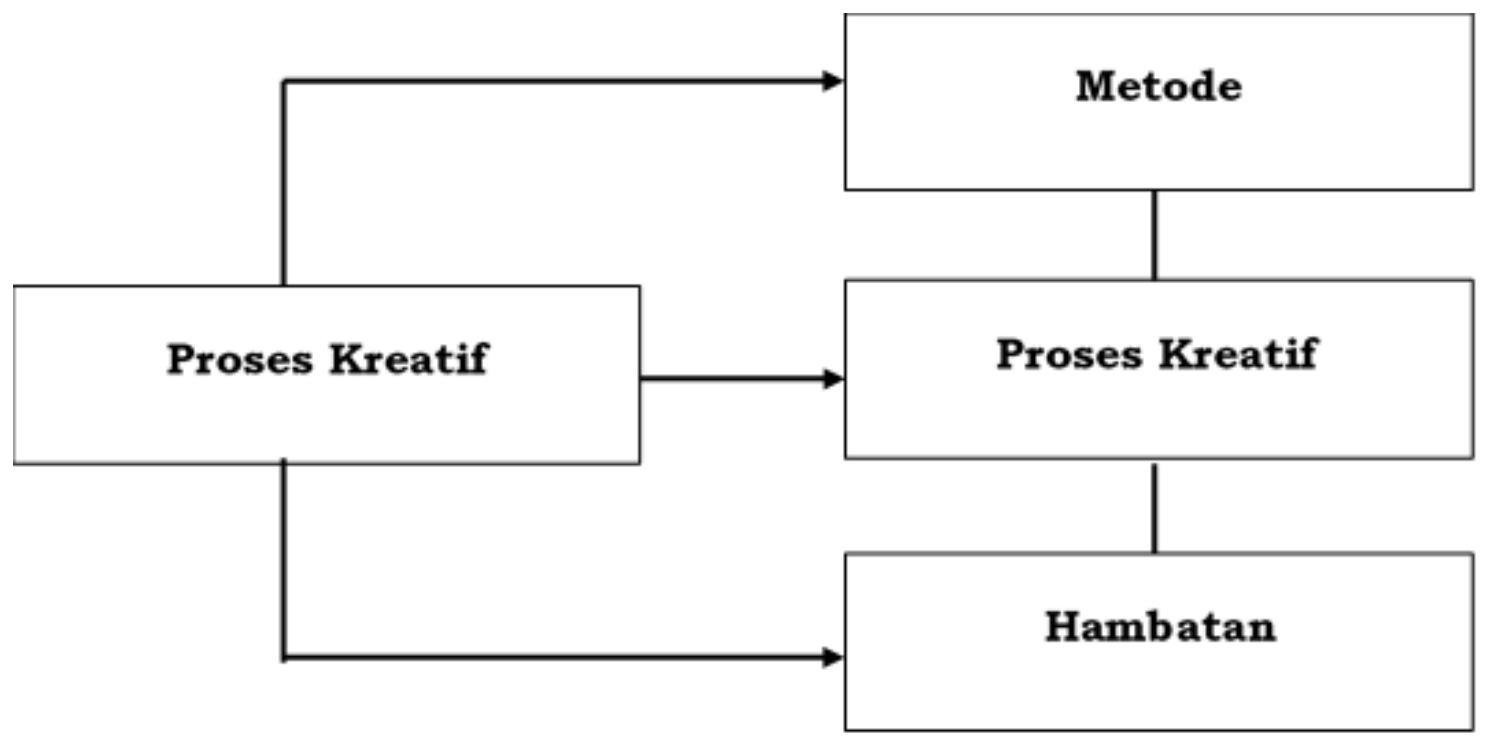

Gambar I

\section{Proses Kreatif Virtual Photoshoot}

(Sumber : Data Olahan Penelitian 2020)

Berdasarkan Gambar I, maka proses kreatif virtual photoshoot terbagi kepada 3 komponen, dimana komponen yang pertama adalah metode virtual photoshoot.

Secara teknis mengenai Virtual Photoshoot, secara umum proses atau metode yang digunakan untuk menghasilkan suatu gambar atau foto dari suatu objek dengan merekam pantulan suatu cahaya yang mengenai objek tersebut pada media yang dirasa peka terhadap cahaya, pada dasarnya seperti itulah prinsip kerja sederhana mengenai proses fotografi sehingga menghasilkan sebuah gambar. Sedangkan virtual photoshoot secara teknis dibutuhkan kemampuan khusus yang didukung dengan media yang compatible. Hal tersebut dikarenakan pemotretan dilakukan melalui media software/aplikasi video call. Sehingga dibutuhkan penyesuaian dan teknis khusus agar hasil yang diperoleh sesuai dengan yang diharapkan. Hal ini didukung dengan informasi narasumber penelitian sebagai berikut:

"Secara teknis itu kalo saya coba jelasin sih, sebenernya gampang-gampang susah, karena yang unik dari virtual photoshoot ini tuh sebenernya kita engga saling ketemu antara si fotografer \& model atau objek yang akan kita foto, bermodalkan jejaring media digital kaya zoom meeting, atau google meets, yang notabenenya support buat video conference, jadi dari situlah interaksi untuk proses virtual photoshootnya.

Berdasarkan pemaparan informan penelitian, proses yang membedakan virtual photosoot dengan pemtretan pada umumnya adalah dengan tidak bertemua fotografer dengan model, dimana penggunaan media software/apliaksi video call memiliki peranan vital dalam menentukan hasil fotografi yang dilakukan. Selain daripada itu bekal kemampuan secara teknis dan kerjasama dengan model atau objek yang akan difoto menjadi tolak ukur utama teknis Virtual Photoshoot dapat dilakukan.

Proses kreatifitas yang tinggi dibutuhkan dalam virtual photoshoot Dimana dengan banyaknya keterbatasan yang dihadapi dibandingkan dengan metode konvensional menyebabkan proses kreatifitas fotografer menjadi kunci untuk mendapatkan hasil yang maksimal. Dimana proses kreatif secara lebih jelas dapat dilihat pada hasil wawancara dengan informan penelitian sebagai berikut:

"Dalam menemukan kreatifitas ketika proses virtual photoshoot, yaitu ketika dalam membentuk komposisi karena secara teknis angle yang terbatas ketika sebenarnya proses virtual photoshoot itu 
kita lakukan secara dua dimensi melalui layar laptop atau PC kita, disitulah kita harus bias menyiasati proses kreatif seperti banyak menggunakan elemen pantulan kaca atau mirror, atau refleksi cahaya-cahaya yang bias kita direct di sekitar ruangan tempat objek kita melakukan poshe"

Pemilihan media yang tepat menjadi hal utama untuk melakukan proses Virtual Photoshoot, seperti halnya fitur yang memang memiliki Videocall, atau Video Conference menjadi elemen utama untuk dapat melakukan Virtual Photoshoot tersebut, seperti halnya keberadaan konvergensi media dalam industri fotografi. Untuk menerangkan konvergensi sebagai proses penggabungan antara industri media, industri komputansi telekomunikasi dan menyatukanya dalam bentuk digital.

Dalam menjalankan proses virtual photoshoot terdapat berbagai kendala yang dihadapi fotografer, dimana proses pengarahan gaya melalui Virtual Photoshoot mengalami keterbatasan pada ruang, sebaran cahaya yang mana penyesuaian ruang dilakukan oleh model objek fotografi. Sehingga dibutuhkan penyesuaian dan interaksi yang maksimal diantara fotografer dengan model yang terpisah. Hal ini sejalan dengan pendapat informan penelitian yang menyatakan bahwa:

"keterbatasan ruang gerak karena dihadapkan dengan dua dimensi ruang yang membatasi angle pada saat melakukan virtual photoshoot, dan kendala tersebut yang sering ditemui dan jadi tantangan"

\section{Pembentukan Kepercayaan Pihak Eksternal}

Skema hasil penelitian mengenai pembentukan kepercayaan pihak eksternal yaitu konsumen atau calon konsumen yang akan menggunakan jasa Virtual Photoshoot secara ebih jelas dapat dilihat pada gambar sebagai berikut:

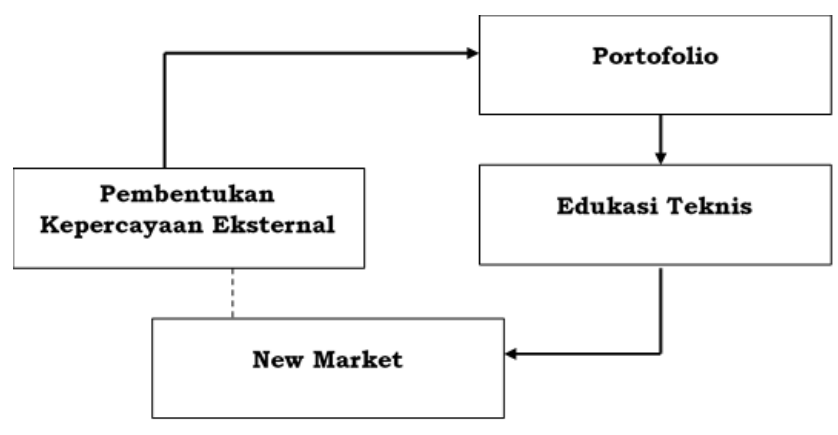

Gambar 2

\section{Pembentukan Kepercayaan Konsumen}

(Sumber : Data Olahan Penelitian 2020)

Dalam membentuk sebuah kepercayaan kepada konsumen, maka dibutuhkan reputasi yang dimata konsumen, dimana reputasi fotografer dapat dilihat pada seberapa baik dan berpengalaman seorang fotografer dalam melakukan kegiatan fotografi. Dimana rangkaian pengalaman tersebut menjadi value yang dilihat oleh konsumen.

Portofolio adalah rangkaian hasil kerja yang telah dilakukan, dimana portofolio menjadi elemen penting yang dapat disampaikan kepada konsumen atau calon konsumen, dalam metode Virtual Photoshoot atau konvensional, portofolio kerja yang banyak dan terdiri dari berbagai jenis konsumen menjadi modal yang dapat digunakan fotografer dalam menarik minat konsumen untuk menggunakan jasa nya.

Portofolio yang telah terbentuk dengan baik, kemudian menjadi modal pemasaran melalui media sosial Instagram dan media-media lainya seperti youtube, facebook sebagai media yang paling banyak digunakan dalam memasarkan jasanya.

Aspek penting lainya dalam meningkatkan kepercayaan konsumen dalam menggunakan metode virtual photoshoot adalah penyampaian teknis yang sederhana dan mudah dimengerti oleh konsumen, karena sejatinya virtual photoshoot membutuhkan adaptasi yang lebih dibandingkan dengan metode fotografi konvensional, sehingga edukasi, interaksi dan komunikasi menjadi faktor kunci dalam meningkatkan kepercayan konsumen. Hal ini 
sejalan dengan pendapat informan penelitian yang menyatakan bahwa:

"Membangun kepercayaan ke client atau calon client tentunya engga gampang yah, perlu tahap adaptasi, bahkan negosiasi pun kita lakuin secara virtual, dan persentasi sampling dari portfolio saya sebelumnya pun melalui zoom meeting, setelah client tau secara teknis baru client atau calon client percaya, dan pada saat itulah proses dealing atau appointment berlangsung.

Dalam rangka menjaga kegiatan perusahaan tetap berjalan, maka salah satu aspek yang dilakukan oleh para foografer pelaku metode virtual phosotshoot adalah dengan mencari pangsa pasar atau kaonsumen yang baru. Dimana penawaran dilakukan secara kepada konsumen baru melalui word of mouth ataupun media sosial seperti Instagram dan media sosial lainya.

\section{Media Yang Digunakan Virtual Photoshoot}

Perkembangan dalam teknologi informasi dan komunikasi yang begitu cepat ditandai dengan perkembangan alat komunikasi. Cepatnya perkembangan industri teknologi komunikasi dapat didasarkan pada perkembangan teknologi komunikasi, sejarah perkembangan dalam teknologi informasi, dan sejarah teknologi informasi. Perubahan yang terjadi ini jelas mempengaruhi pola komunikasi dan hubungan yang sosial yang terjadi dimasyarakat seperti komunikasi bisnis ataupun komunikasi organisasi, pendidikan atau komunikasi pembelajaran, komunikasi kesehatan, komunikasi pemasaran utamanya dalam strategi komunikasi pemasaran, komunikasi internasional, dan lainlain.

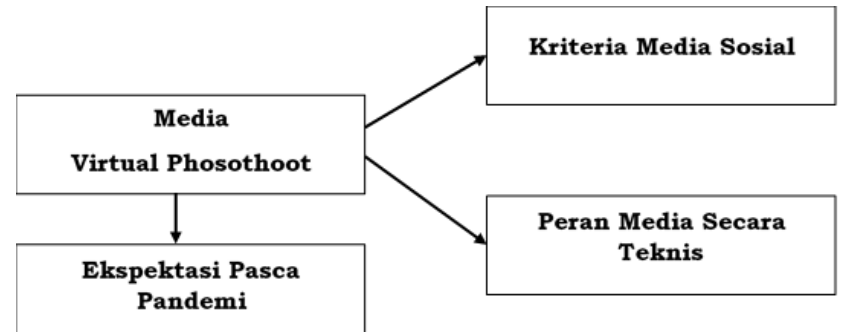

Gambar 3

\section{Media Virtual Photoshoot}

(Sumber : Data Olahan Penelitian 2020)

Untuk menjawab keberadaan media dalam Virtual Photoshoot yaitu terletak kepada kriteria media sosial yang digunakan untuk menunjang teknis pada saat pelaksanaan Virtual Photoshoot. Dimana keberadaan sebuah fitur atau alat digital pendukung yang memiliki kegunaaan untuk melakukan sebuah interksi komunikasi secara timbal balik dengan menampilkan visualisasi kita secara langsung dengan lawan bicara atau sering disebut dengan fitur Videocall atau Video Conference yang pada akhirnya peran media ini menjadi tonggak utama proses Virtual Photoshoot dapat dilaksanakan.

Pada saat media digital mengambil peran perihal metode Virtual Photoshoot pada akhirnya teknologi kembali menjadi pilar utama untuk menopang jalannya sebuah inovasi baru pada industri kreatif ditengah pandemi saat ini, hal ini serupa dengan kaitan teori mengenai keberadaan teori determinisme yang disampaikan McLuhan dalam tulisannya The Guttenberg Galaxy: The Making of Typographic man. Ia juga sempat menulis buku yaitu Understanding Media (1964), ia menulis tentang pengaruh teknologi. Ide dasar dalam teori ini adalah perubahan yang terjadi dalam berkomunikasi akan membentuk identitas dan karakteristik manusia itu sendiri.

Teknologi akan berpengaruh terhadap pola hidup dalam berfikir, berperilaku dalam masyarakat dan menjadi manusia yang lebih kekinian mengikuti zaman. Teknologi dapat merubah budaya yang dibentuk oleh bagaimana caranya manusia berkomunikasi. Ada beberapa tahap manusia dalam mengenal media komunikasi. Pertama, teknologi dapat merubah kebudayaan. Kedua, jenis-jenis komunikasi dapat membentuk manusia. Ketiga, yang membentuk peralatan untuk berkomunikasi dan akhirnya peralatan untuk berkomunikasi yang digunakan akan membentuk atau memengaruhi kehidupan

\section{CONCLUSIONS}


Simpulan dalam penelitian ini adalah sebagai berikut:

1. Proses kreatifitas dalam virtual photoshoot tediri metode virtual photoshoot, dimana metode yang digunakan dilakukan melalui fitur videocall, sedangkan pada aspek proses kreatif diperlukan instuisi dan dukungan ruang maupun pencahayaan yang baik dan keterbatasan dalam ruang gerak fotografi dalam virtual photoshoot menjadi tangantangan tersendiri yang dihadapi oleh para fotografer yang menggunakan metode virtual photoshoot

2. Kepercayaan konsumen dapat dibangun melalui ortofolio yang baik, untuk kemudian dilakukan penawaran secara langsung kepada konsumen. Selain itu pemasaran melalui berbagai media sosial menjadi aspek yang digunakan dalam rangka mencari segmentasi pasar baru.

3. Media yang digunakan dalam virtual photoshoot adalah fitur video call sebagai teknis pelaksanaan dan media sosial dalam aspek pemasaranya. Sedangkan keterlibatan teknologi informasi/digital menjadi salah satu upaya dalam meningkatkan peluang pasar ditengah berlangsungnya pandemic Covid-19

\section{REFERENCES}

Agustina, F., Ansori, N., \& Pradana F.A, T. (2014). Pemetaan Industri Kreatif Dan Penentuan Kompetensi Inti Bangkalan. Jurnal Teknik Industri, 14(2), 131. https://doi.org/10.22219/jtiumm.vol14.no2. 131-138

Aryanto, A. (2020). Di Tengah Covid-19, Pemasaran Online dan Digital Branding Jadi Pilihan. Https://Www.Wartaekonomi.Co.Id/, 1.

Budiman, Arif, E., \& Roem, E. R. (2019). Pemanfaatan Media Sosial Sebagai Sarana Promosi Perpusda Kabupaten Belitung Timur. Jurnal Ranah Komunikasi, 3, 34-44.

Dewi, W. A. F. (2020). Dampak Covid-19 Terhadap Implementasi Pembelajaran Daring Di Sekolah Dasar. Edukatif: Jurnal Ilmu Pendidikan, 2(1), 55-61. https://doi.org/https://doi.org/10.31004/edu katif.v2i1.89

Hanana, A., Anindya, A., \& Elian, N. (2020). Transformasi Media Youtube Dan Televisi (Analisis Fungsi Dan Konsumsi Media Youtube Dan Televisi Di Kota Padang). Jurnal Ranah Komunikasi (JRK), 4(2), 186. https://doi.org/10.25077/rk.4.2.186194.2020

Hidayat, D., \& Noeraida. (2020). Pengalaman Komunikasi Siswa Melakukan Kelas Online Selama Pandemi COVID-19. Jurnal Ilmu Komunikasi Efek, 3(2), 172-182. https://doi.org/10.32534/jike.v3i2.1017

Marvela. (2020). Wabah Covid-19, Pekerja Industri Kreatif dan Media Kehilangan Job. Https://Seleb.Tempo.Co/, 1.

Nugraha, B. (2020). Dampak Covid-19, Pekerja Industri Kreatif Kehilangan Pendapatan. Https://Www.Vivanews.Com/, 1.

Nugroho, Y. W. (2014). Kuliah Pilihan Pada Kurikulum Desain. LPPM, 1-9.

Peranika, N. W. P., \& Martana, I. N. A. (2018). Diunggah Melalui Sistem Internet Dan Sanksi Hukum Bagi Pengguna Ilegal *. Journal Ilmu Hukum, 1-15.

Perwitasari, N. H. (2020). 4 Cara Agar Bisnis Tetap Bertahan Selama Pandemi Corona COVID-19 Baca selengkapnya di artikel "4 Cara Agar Bisnis Tetap Bertahan Selama Pandemi Corona COVID-19." Https://Tirto.Id/, 1.

Pratama, N. A., \& Hidayat, D. (2020). Pengetahuan dan Perilaku Masyarakat Memaknai Social Distancing. Jurnal Digital Media \& Relationship, 2(1), 1-10.

Purnomo, A. S. A. (2018). Fotografi Di Era Media Sosial : Studi "Toko Memorabilia" Karya Agan Harahap. Jurnal Bahasa Rupa, 1(2), $81-88$.

https://doi.org/10.31598/bahasarupa.v1i2.20 0

Rahmasari, L. (2011). Pengaruh Supply Chain Management Terhadap Kinerja perusahaan dan Keunggulan Bersaing (Studi Kasus pada Industri Kreatif di Provinsi Jawa Tengah). Majalah Ilmiah INFORMATiKA, 2(3), 89103.

Sirat, M., Awaluddin, I., Farizki, S., Sirat, M., Awaluddin, I., \& Farizki, S. (2019). Conduct And Its Effect On Performance Company In Photography Industry In Bandar Lampung City. Jurnal Ekonomi Pembangunan, 8(3), 
243-266.

Tjin, E. (2020). Dunia Fotografi Tak Akan Sama

Lagi

Setelah

Corona?

Https://Inet.Detik.Com/.

Widiatmojo, R. (2018). Kekerasan Simbolik Terhadap Perempuan Dalam Fotografi Portrait di Group Facebook: Studi pada Komunitas Fotografi Indonesia. Jurnal Komunikasi Indonesia, 5(2). https://doi.org/10.7454/jki.v5i2.8906

Yunus, N. R., \& Rezki, A. (2020). Kebijakan Pemberlakuan Lockdown Sebagai Antisipasi Penyebaran Corona Virus Covid19? Jurnal Sosial Dan Budaya Syar-I, 7(3), 227.

https://doi.org/10.15408/sjsbs.v7i3.15048 